Research papers

\title{
Impacts of predicted climate change on groundwater flow systems: Can wetlands disappear due to recharge reduction?
}

\author{
Tímea Havril $^{\mathrm{a}, *}$, Ádám Tóth ${ }^{\mathrm{a}}$, John W. Molson ${ }^{\mathrm{b}}$, Attila Galsa ${ }^{\mathrm{c}}$, Judit Mádl-Szőnyi ${ }^{\mathrm{a}}$ \\ ${ }^{a}$ ELTE Eötvös Loránd University, Department of Physical and Applied Geology, József and Erzsébet Tóth Endowed Hydrogeology Chair, Budapest, Hungary \\ ${ }^{\mathrm{b}}$ Laval University, Department of Geology and Geological Engineering, Quebec City, Canada \\ ${ }^{\mathrm{c}}$ ELTE Eötvös Loránd University, Department of Geophysics and Space Sciences, Budapest, Hungary
}

\section{A R T I C L E I N F O}

\section{Article history:}

Available online $\mathrm{xxxx}$

This manuscript was handled by $C$. Corradini, Editor-in-Chief, with the assistance of Brian D. Smerdon, Associate Editor

\section{Keywords:}

Groundwater level decrease

Flow system hierarchy

Transient numerical simulation

Groundwater-dependent ecosystems

Tihany Peninsula

Climate change reduced recharge

\begin{abstract}
A B S T R A C T
Climate change can directly influence groundwater systems through modification of recharge. Affecting not only groundwater levels and flow dynamics, climate change can also modify the fragmentation and hierarchy of groundwater flow systems. In this study, the influence of climate change - impacted recharge on groundwater levels and on inter-connected groundwater flow patterns is evaluated. Special emphasis is placed on how flow system hierarchy may change, to examine possible consequences on groundwater-related shallow surface water bodies and on groundwater - surface water interaction. As a test site with no significant anthropogenic impacts, the Tihany Peninsula in Hungary was an ideal area for the study. We address the following issues: i) How might a groundwater system, including groundwater-surface water interaction, be modified by predicted climate change?, ii) Given the variable groundwater levels and flow patterns, how will the water levels and fluxes be impacted around surface water bodies?, and iii) How sensitive are groundwater-related wetlands to these changes, and will they be maintained or will they eventually disappear? In order to answer these questions, two-dimensional transient numerical simulations were performed based on site-specific measurements and climatic prediction at the Tihany Peninsula. Results show that future climate trends can cause dynamic evolution and dissipation of transient groundwater flow systems, and the characteristic flow system hierarchy can change from nested flow systems to a set of single flow cells. Preservation of associated groundwaterdependent ecosystems would be challenging under these conditions since long-term climate change could potentially have serious consequences, including wetland disappearance. Understanding these transient processes in two-dimensions can also help to set-up three-dimensional site-specific models.
\end{abstract}

(c) 2017 Elsevier B.V. All rights reserved.

\section{Introduction}

Hydrological observations over the past several decades have provided ample evidence that water resources can be strongly affected by climate change, with widespread consequences for society and ecosystems (Bates et al., 2008). Despite the development of advanced climate forecasting methods, the degree of climate change is largely uncertain because of variability of global circulation models (GCMs) and greenhouse gas emission scenarios, and because of numerous complex feedback processes. Moreover, hydrological studies of climate change mainly focus on surface water, while groundwater usually receives less attention. Our present understanding of how regional climate predictions impact subsurface water resources and flow systems, and our knowledge

\footnotetext{
* Corresponding author.

E-mail address: timihavril@gmail.com (T. Havril).
}

about the dynamic relationship between groundwater and climate is therefore somewhat limited (Taylor et al., 2013). This insight is also confounded by the relatively long residence time of groundwater, which is likely to delay, attenuate and disperse the effects of climate change (Chen et al., 2004; Gurdak, 2008). Nevertheless, scientific interest regarding the effects of future hydrologic conditions on groundwater has grown rapidly over the last decade.

Predictions based on the Intergovernmental Panel on Climate Change (IPCC) show significant global warming and changes in frequency and amount of precipitation from the beginning of the $21^{\text {st }}$ century. Sandström (1995) showed that a $15 \%$ reduction in precipitation, with no change in temperature, could result in a $40-50 \%$ reduction in recharge. However, higher air temperatures are likely to increase evapotranspiration, which may also result in a reduction of water that can reach the saturated zone. Therefore, as $\mathrm{Ng}$ et al. (2010) highlighted, the predicted changes in recharge may be greater than changes in precipitation, and the combined effects 
of simultaneous changes in these hydrologic drivers can significantly modify groundwater replenishment.

Climate change and variability will likely have diverse effects on groundwater recharge rates and mechanisms (Kundzewicz et al., 2008; Aguilera and Murillo, 2009). While many studies have predicted reduced future recharge (e.g. Brouyère et al., 2004; Herrera-Pantoja and Hiscock, 2008; Neumann et al., 2017), others found climate change will likely result in increased recharge rates (e.g. Jyrkama and Sykes, 2007; Kovalevskii, 2007). Both changes would have significant effects not only on groundwater levels, but could also modify the fragmentation and hierarchy of groundwater flow systems, including their dimensions, relative positions, and divisions between local, intermediate and regional flow. Although several regional-scale studies have been published (Green et al., 2011; Taylor et al., 2013; Döll and Fiedler, 2007) and site-specific investigations have been completed dealing with the impacts of climate change on groundwater (e.g. SerratCapdevila et al., 2007; Ng et al., 2010; Hanson et al., 2012), studies which focus on the modification of groundwater system hierarchy are under-represented in the literature.

Surface-water bodies are integral parts of groundwater flow systems and their water and nutrient budgets are thus strongly influenced by groundwater. Changes in flow system hierarchy could modify this interaction between groundwater and surface water. Local flow systems are affected the most by climate change (Kurylyk et al., 2014), and are thus the most vulnerable to these changes, not only with respect to fluxes and water balance, but also with respect to water quality. Many groundwater resources feeding groundwater-dependent ecosystems are also non-renewable on meaningful time scales (Kløve et al., 2011a,b), therefore climate change can also induce significant stress on these communities (Earman and Dettinger, 2011; Candela et al., 2012; Tujchneider et al., 2012; Barron et al., 2012; Kløve et al., 2014).

While field observations are essential to explore and document these surface and subsurface changes, numerical groundwater models are often the only feasible means of interpreting data and producing insight into the future response of groundwater systems to climate change (Green et al., 2011) or any other anthropogenic effects (Singh, 2014).

Using 2D groundwater flow simulations, the main goals of this project were to evaluate the influence of climate-change altered recharge on groundwater levels and coupled effects on the connected groundwater flow patterns, with special emphasis on changes to flow system hierarchy. We also aim to examine the possible consequences on groundwater-connected shallow surface water and groundwater - surface water interaction.

The wetlands of Tihany Peninsula (Hungary), which can be characterized by a sub-Mediterranean climate, are in hydraulic communication with groundwater since they are almost exclusively maintained by local groundwater flow systems (Tóth et al., 2016). These shallow surface water bodies can be identified by their unique groundwater-dependent ecosystems which depend on their relative hydraulic position. Since no significant anthropogenic impacts have affected the groundwater system of this European Natura 2000 site (European Commission), it is an ideal area for examining the impact of climate change on groundwater levels and flow systems. Moreover, although beyond the scope of the study, preservation of the wetland environment and biodiversity of this natural conservation area is of critical importance. Climate change would have an unfavorable impact on these ecosystems by decreasing or even eliminating surface water, which has not yet been studied in this environment.

At the Tihany Peninsula study site, the main questions of the study are: i) How might the groundwater system, including groundwater-surface water interaction, be modified by predicted climate change?, ii) Given the variable groundwater levels and flow patterns, how will the water levels and fluxes be impacted around surface water bodies?, and iii) How sensitive are the groundwaterrelated wetlands to these changes, and will they be maintained or will they eventually disappear?

Addressing these questions could help to identify the potential effects of climate change on groundwater flow patterns, and its consequences on groundwater-related shallow surface water bodies and ecosystems. This insight could also help to prepare for the effects of climate change and to protect and develop the local water resources. Additionally, the understanding of the basic questions can help to set-up site-specific 3D models.

\section{Study site and predicted climate change}

\subsection{Location and hydrogeologic setting}

The Tihany Peninsula, which lies within Lake Balaton, Hungary, and separates the basin into two sub-basins, is part of the BakonyBalaton Highland Volcanic Field in the western part of the country (Fig. 1.). The maximum length of the peninsula is $5 \mathrm{~km}$ (in the NWSE direction), its maximum width is $3.5 \mathrm{~km}$ (in the SW-NE direction), and is connected to the mainland by a $1.5 \mathrm{~m}$ wide ness. The highest point of the site ( $235 \mathrm{~m}$ asl) is $131 \mathrm{~m}$ above the average water level of Lake Balaton (104 m als). Two perennial lakes are found on the peninsula: Outer Lake and Inner Lake. Outer Lake is a palustrine wetland which lies at $114.6 \mathrm{~m}$ asl surface elevation, representing the deepest area of the peninsula; Inner Lake, which is a lacustrine wetland, can be found at $124.4 \mathrm{~m}$ asl. A third lacustrine wetland, which is a seasonal lake (Rátai-csáva), is located at $126 \mathrm{~m}$ asl and forms a temporary water body, appearing only after wet years and snowmelt (Fig. 1a).

The geologic structure is quite complex in this area (Fig.1b). The bedrock is Silurian shale, functioning as an aquiclude (GondárSöregi and Gondár, 1988) which is overlain by Permian sandstone (Haas et al., 1999). Mesozoic and Miocene carbonate formations (limestone and dolomite) are superimposed on Paleozoic sequences in several layers of 10-100 m thickness (Haas et al., 1999). Miocene clay marl, silt, and sand sequences alternate over the carbonate units. Mio-Pliocene volcanics and maar structure formations cut through the siliciclastic beddings (Sacchi et al., 1999; Horváth et al., 2010). A thin (maximum $10 \mathrm{~m}$ ) discontinuous Pleistocene-Holocene fine-grained cover is the youngest formation (Fig. 1b).

The wetlands are located in paleo-maar structures, which form closed basins, and are not fed by any streams, therefore they were formerly assumed to be independent of each other, and recharged exclusively from precipitation. According to anecdotal baseline estimates (which are based on historical data and on observations of the water conditions of the peninsula), the water level of Inner Lake started to decrease immediately following the construction of a canal which was built at the beginning of the $19^{\text {th }}$ century to drain water from Outer Lake. This phenomenon indirectly reflected the subsurface connection between Inner and Outer Lake.

The peninsula-scale flow systems, including the hydraulic connection between these wetlands and Lake Balaton, as well as the impact of hydrostratigraphic units on the local flow patterns, were revealed by Tóth et al. (2016) using 3D groundwater flow simulations. They also showed that wetlands are maintained almost exclusively by local groundwater flow systems and water levels within these shallow surface water bodies are thus an extension of the groundwater level. Complex hierarchical flow patterns with high Darcy fluxes were inferred only near-surface, above the uppermost approx. $30 \mathrm{~m}$ thick aquitard unit (a Mio-Pliocene clay marl layer), i.e. primarily within the upper $100 \mathrm{~m}$ of the hydrogeological system. Only a small fraction of recharge enters the deeper 


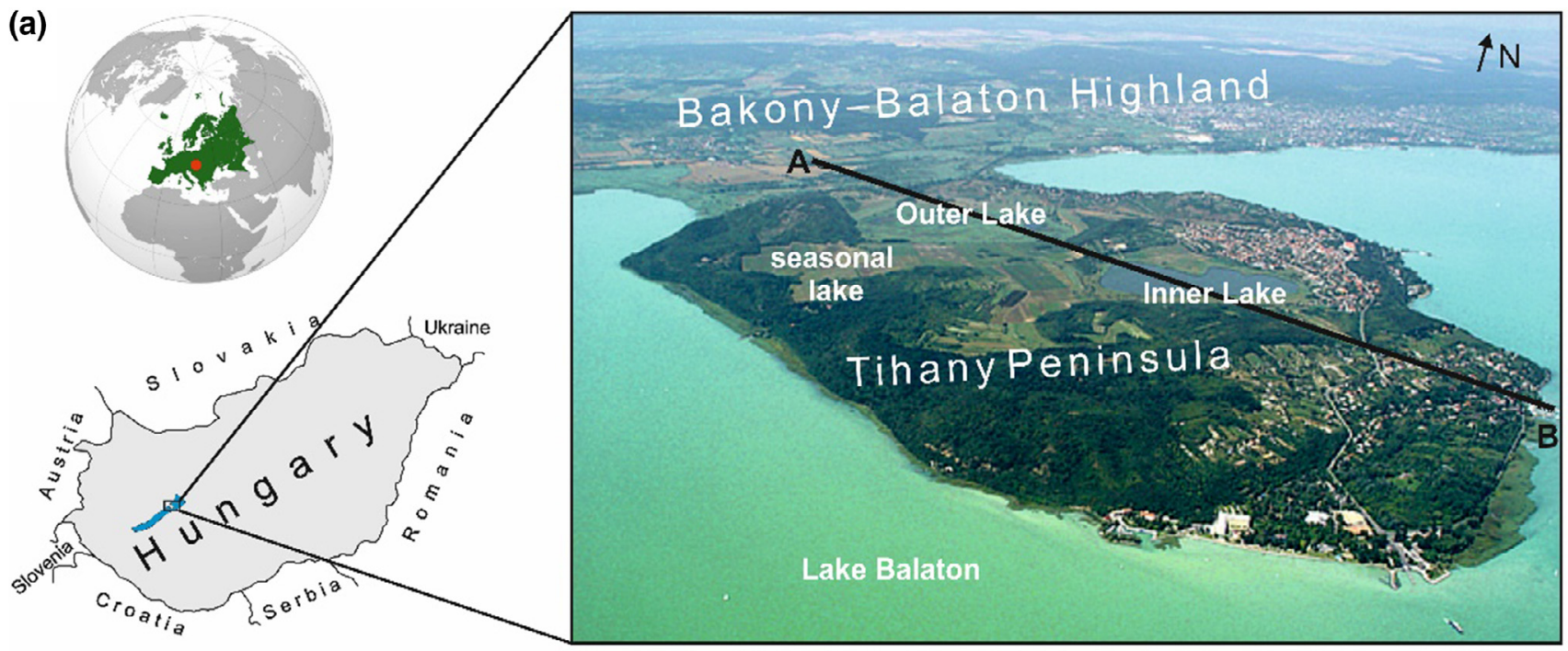

(b) $\mathrm{m}$ asl
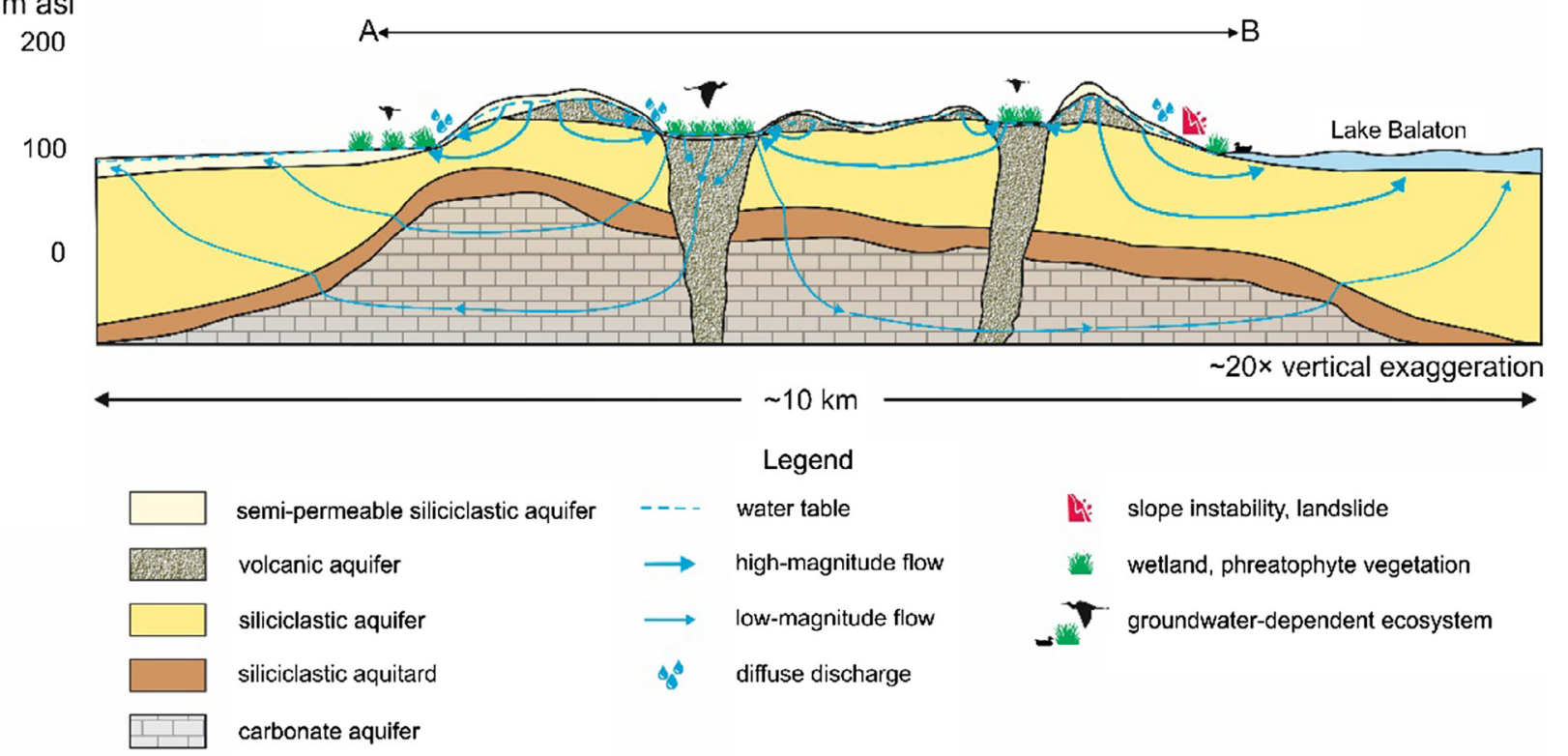

semi-permeable siliciclastic aquifer

volcanic aquifer

siliciclastic aquifer

siliciclastic aquitard

carbonate aquifer
Legend

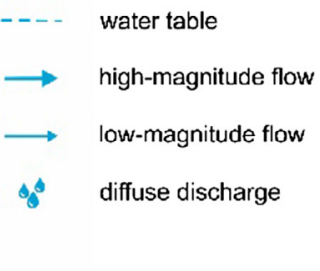

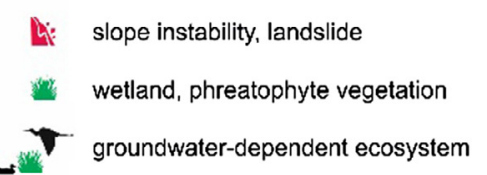

groundwater-dependent ecosystem

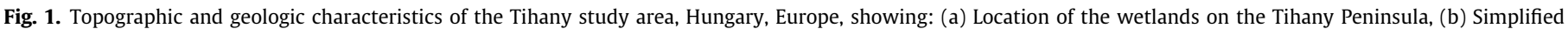
geology, conceptual peninsula-scale groundwater flow pattern and related natural surface manifestations (Tóth et al., 2016).

formations where the flow pattern is simpler, the flow rates are lower, and water flows below Lake Balaton.

Monthly water-level measurements from shallow potentiometers at the shoreline and in the vicinity of the wetlands, and results of seasonal water chemistry analyses (major ions, $\mathrm{pH}$, electric conductivity and temperature) were available from successive very dry and rainy years (Havril, 2012). Havril et al. (2012) showed that a seasonal lacustrine wetland - which is the highest elevated depression on the peninsula - is the most sensitive to changes in precipitation. Measured water level fluctuations between the dry and wet periods were $>2.5 \mathrm{~m}$, and its water contains low total dissolved solids (TDS $\sim 960 \mathrm{mg} \mathrm{l}^{-1}$ ), therefore it can be characterized as a recharge-type lake. Outer Lake, being the deepest area of the peninsula, is a discharge-type lake, which is less sensitive to fluctuations in precipitation due to the buffering effect of continuous subsurface inflow. Its water level decrease was only $0.6-0.7 \mathrm{~m}$ during the dry period, with the lake water containing higher TDS (1700 $\left.\mathrm{mg} \mathrm{l}^{-1}\right)$. Inner Lake is a through-flow type lake with intermediate water level fluctuations $(\sim 0.8 \mathrm{~m})$ and TDS values $\left(1200 \mathrm{mg} \mathrm{l}^{-1}\right)$. Therefore, the hydraulic behavior and major ion content of these wetlands depend strongly on the position of the lakes within the groundwater system of the peninsula. Results show strong similarities with the findings of Cheng and Anderson (1994) who revealed, in the case of three through-flow lakes at different elevations, groundwater fluxes into and out of the lowestelevation lake were higher and more stable.

\subsection{Potential effects of predicted climate change on recharge}

The Tihany Peninsula is characterised by a sub-Mediterranean climate with approx. $600 \mathrm{~mm}$ annual precipitation and a $10^{\circ} \mathrm{C}$ average annual air temperature. Based on regional climate change modelling predictions for Hungary, the annual precipitation is likely to decrease by about $20 \%$ by the end of the century (Pieczka et al., 2011). Significant increases in winter precipitation (10-30\%) and significant decreases in summer precipitation 
(15-40\%) are also predicted. Since the expected increase in annual temperature is $4-5.4^{\circ} \mathrm{C}$, the probability of drought occurrence is also expected to increase (Bartholy et al., 2014).

To predict the effects of a specific climate change model on the Tihany Peninsula groundwater system, we focused on the most sensitive hydrologic parameters during the calculation of local recharge, as determined from our preliminary study (Havril et al., 2012; Tóth et al., 2016). Due to the recent climatic conditions of the area with moderate precipitation, overland flow was considered negligible, as the rainfall rate rarely exceeds infiltration capacity and most of the rainwater can infiltrate and is assumed to reach the saturated zone. Through-flow was therefore also neglected. Since no streams or rivers are found in the study site, the wetlands are thus situated in closed basins, i.e. streamflow is zero. Groundwater recharge was thus estimated as the precipitation less evapotranspiration, while surface runoff was neglected. Moreover, runoff would also decrease in time due to decreasing precipitation. We assume that uncertainties generated by this site-specific simplification are not significant compared to the uncertainties inherent in the climate change predictions. Furthermore, the current study focuses on the response of a groundwater flow system to climate change influenced recharge and its related consequences rather than predicting exact site-specific wetland water levels. However, in other areas where surface runoff is important, runoff should be included in the recharge calculation.

Evapotranspiration was calculated based on the Turc formula (Turc, 1961), which requires only limited data, and which is given as

$E=\frac{P}{\sqrt{0.9+\frac{P^{2}}{K^{2}}}}$

where $\mathrm{E}$ is evapotranspiration $\left(\mathrm{mm} \mathrm{yr}^{-1}\right), \mathrm{P}$ is annual precipitation $\left(\mathrm{mm} \mathrm{yr}^{-1}\right), K=300+25 T+0.05 T^{3}$ and $\mathrm{T}$ is the mean annual air temperature $\left({ }^{\circ} \mathrm{C}\right)$. Assuming $\mathrm{P}=600 \mathrm{~mm} \mathrm{yr}^{-1}$ and $\mathrm{T}=10^{\circ} \mathrm{C}$ which are characteristic for the peninsula, the current evapotranspiration rate (E) is $435 \mathrm{~mm} \mathrm{yr}^{-1}$. Subtracting $\mathrm{E}$ from precipitation $(P)$, the current groundwater recharge is $165 \mathrm{~mm} \mathrm{yr}^{-1}$. Therefore, under current conditions, only approx. $27 \%$ of precipitation can reach the saturated zone and recharge the groundwater system.

Taking into account a $20 \%$ decrease in precipitation and a $4{ }^{\circ} \mathrm{C}$ increase in temperature as predicted by climate models (Pieczka et al., 2011, Bartholy et al., 2014), a 67\% decrease in recharge is expected for the area by the end of the century (2100), which is a significant change. Assuming the same degree of precipitation decrease and temperature increase at the beginning of the next century, the estimated change in groundwater recharge was extended by a period of 20 years (to 2120 ). The predicted changes in precipitation, temperature, evapotranspiration and groundwater recharge over the next 100 years are summarized in Fig. 2.

\section{Numerical simulation approach}

In the current study, future changes in groundwater levels and flow system characteristics due to climate change were simulated using the transient numerical flow module within the HeatflowSmoker code (Molson and Frind, 2015) along a 2D vertical plane. Heatflow-Smoker is a finite element code which couples densitydependent groundwater flow and heat transport.

The model solves the continuity equation for flow (Bear, 1972) which can be expressed as

$\frac{\partial}{\partial x_{i}}\left[K_{i, j}(T)\left(\frac{\partial \psi}{\partial x_{j}}+\rho_{r}(T) \cdot \bar{n}_{j}\right)\right]=S_{s} \frac{\partial \psi}{\partial t}$ where $x_{i j}$ are the $3 D$ spatial coordinates $(m), K_{i j}(T)$ is the temperature-dependent hydraulic conductivity tensor $\left(\mathrm{m} \mathrm{s}^{-1}\right), \psi$ is the equivalent freshwater head $(m), \rho_{r}(T)$ is the temperaturedependent relative density of water $(-), S_{s}$ is the specific storage $\left(\mathrm{m}^{-1}\right)$, and $\mathrm{t}$ is time $(\mathrm{s})$.

Based on the findings of Tóth et al. (2016) regarding the vertical extent of active groundwater flow at the study site, the current analysis also focuses on the processes acting in the upper approx. $100 \mathrm{~m}$, where the most significant changes in the flow field are expected. Since the simulated flow domain is very shallow $(<130 \mathrm{~m})$, and the maximum temperature increase with depth is low $\left(<5{ }^{\circ} \mathrm{C}\right)$, the effect of advective heat transfer could therefore be neglected (An et al., 2015) and only isothermal groundwater flow was simulated, assuming a uniform temperature of $10^{\circ} \mathrm{C}$.

\subsection{Theoretical considerations}

Since our interest in this study was to highlight the possible influence of climate change on groundwater flow systems including consequences on groundwater-related shallow surface water, some simplifications were included in the simulation approach. Although the model is based on a real site, the impact of these simplifications was not expected to be significant since the intent was not to present results as site-specific absolute predictions.

One issue was the assumption of a two-dimensional verticalplane model. While an accurate representation of model dimensionality is important, in this study a 2D simplified system was designed in order to focus on key parameters in parallel (recharge, hydraulic head), neglecting other factors including surface runoff and transverse flow. The two-dimensional model assumes that all groundwater flows in the vertical plane, and that the wetlands thus extend far in the transverse direction. In the real case, as recharge decreases, transverse flow toward this section would tend to maintain surface water levels longer than in the simulated case. The real site would thus also tend to tolerate higher evaporation rates. Moreover, if a wetland is recharging the aquifer, we assume all groundwater remains in this 2D section whereas some could flow out transversely. Consequently, we would overestimate the water flux reaching the downstream lake and thus underestimate its dewatering rate. In both cases, the $2 \mathrm{D}$ model would be somewhat overestimating the effects of climate change. Since our focus has been directed toward understanding dynamically changing flow regimes and looking for general trends and characteristics of these modified flow fields, the $2 \mathrm{D}$ model is considered a reasonable approach for providing the needed insight.

The study area is almost entirely surrounded by Lake Balaton, which represents a regional hydraulic potential minimum (Tóth et al., 2016). Lake water elevations were therefore chosen as first-type (fixed head) flow boundary conditions at the right boundary of the $2 \mathrm{D}$ model. Since the drainage basin of Lake Balaton covers about $20 \%$ of Hungary (approx. $600 \mathrm{~km}^{2}$ ) (G-Tóth et al., 2011), its response to predicted climate change is difficult to predict and beyond the scope of this study. As Bartholy et al. (1995) highlighted, climate can indeed induce changes in the lake level because it is exceptionally shallow ( 3-4 m deep), however its sensitivity to future changes in hydrologic conditions has not yet been studied. In this study, possible future water level decreases in Lake Balaton were estimated based on past water level fluctuations. At present, the mean depth of Lake Balaton is $3.25 \mathrm{~m}$, its mean water level elevation is $104.4 \mathrm{~m}$ asl, and its maximum water level is controlled by a canal. During four consecutive years of drought in 2000-2003, the water level of the lake decreased by $28 \%$, i.e. by approx. $0.9 \mathrm{~m}$ (G-Tóth et al., 2011). Therefore, in this current study, a $1 \mathrm{~m}$ water level decrease (until 2120) was assumed. A sensitivity analysis on the effects of greater water level 


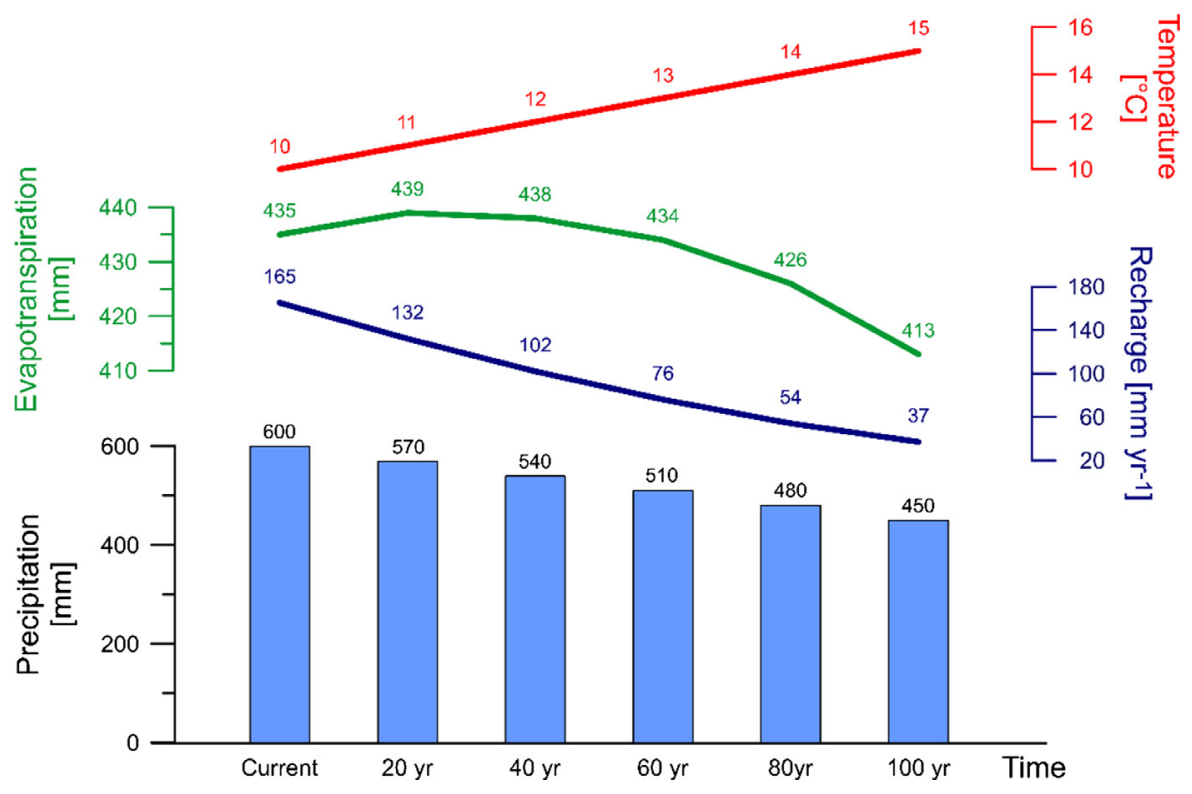

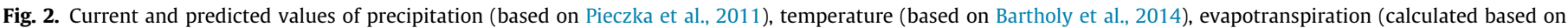
Turc, 1961) and groundwater recharge (subtracting evapotranspiration from precipitation) for the Tihany Peninsula.

reductions on the flow field showed no significant effects on the general conclusions.

Another issue was the prediction of the wetlands' future state will they be maintained or will they eventually disappear? To address this issue, comparisons of the simulated transient groundwater levels with local lakebed bottom elevations were used to follow the changes in water levels of the wetlands during the transient simulations. Although this simulation approach neglects direct precipitation and evaporation at the water surface of the lakes and neglects flow within the unsaturated zone, it does take into account the most significant influence on the lake levels, which is the local groundwater level. This simplification is considered acceptable since these shallow wetlands are situated in closed basins, and are not affected by recharging or discharging stream water.

\subsection{Simulated cases}

Changes in groundwater levels and flow patterns were followed along the 2D vertical section across the peninsula, through Outer and Inner Lakes, as shown in Fig. 3. The $5000 \mathrm{~m}$ long and $130 \mathrm{~m}$ deep model domain was subdivided into a regular network of $500 \times 30$ elements in the $\mathrm{x}$ and $\mathrm{z}$ directions, with each rectangular prism element measuring $10 \mathrm{~m} \times 4.3 \mathrm{~m}$ respectively (with 1 element in the transverse dimension).

As a first step, a steady-state simulation was run based on sitespecific measurements (Havril, 2012), and representing the current groundwater flow system and average water level conditions.

Climate models predict an increasing probability of annual hydrological extreme events (Bartholy et al., 2014), in which shorter-term changes will be superimposed on the longer timescale climatic variability. In order to estimate potential effects of these short-term events on groundwater, flow conditions for the two years with the most extreme hydrological conditions were examined prior to running the transient simulation. Over the past decade, 2010 was an extreme wet year, when the amount of precipitation exceeded the annual $600 \mathrm{~mm}$ average by $50 \%$ (900 $\mathrm{mm}$ ), therefore this case could be considered as a high water level condition. In contrast, 2011 was an extreme dry year with $33 \%$ less precipitation $(400 \mathrm{~mm})$, representing a low water level condition. Based on monthly measured water levels from potentiometers near the lakes (Havril et al., 2012), and on the calculated recharge values accounting for reduced precipitation, two steadystate numerical simulations of groundwater flow were run. However, it should be noted that an extreme dry year following a year with normal or dry conditions could have more significant effects on surface- and groundwater levels, than in this case where it followed a year with an exceptionally high amount of precipitation.

The full transient simulation was run over a period of 100 years, with a time step of $1 \mathrm{yr}$. Over the first 80 years, changes to the hydrologic parameters were based on referenced climate change predictions. Over the subsequent 20 years (at the beginning of the next century, beyond the range of the climate models), the same rate of precipitation decrease and temperature increase was assumed This 20-year extension to the transient simulation was aimed at following the possible additional changes to the hydraulic potential distribution and flow field along the section. Simulated hydraulic head distributions and flow paths were plotted every 20 years.

\subsection{Input parameters, initial and boundary conditions of the model}

Horizontal and vertical hydraulic conductivity $\left(\mathrm{K}_{\mathrm{h}}\right.$ and $\left.\mathrm{K}_{\mathrm{v}}\right)$ and porosity ( $\mathrm{n}$ ) values of the formations were estimated based on integrating site-specific lithostratigraphic and hydrostratigraphic information by Tóth et al. (2016) (Fig. 3). Some hydrostratigraphic data were obtained from electromagnetic surveys. The same hydraulic parameters and hydrostratigraphy were used during both the steady-state and transient simulations.

This shallow system was handled as an unconfined but deep aquifer. During the transient simulation, a uniform specific storage of $S_{s}=0.09 \mathrm{~m}^{-1}$ was applied, which represents a combination of relatively high storativity in shallow sediments (governed by porosity) and relatively low storativity in the deeper fractured rock.

The lower flow boundary condition was defined based on the hydrostratigraphic section of the area (Fig. 3b), where a regional aquitard underlies a layer of clastic deposits which have a 3 -orders of magnitude higher $\mathrm{K}$. The bottom of the system was therefore represented as a no-flow boundary in agreement with 
(a)

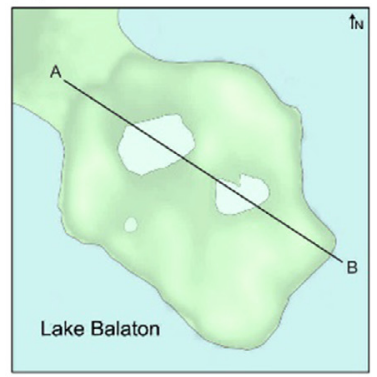

(b)

A NW
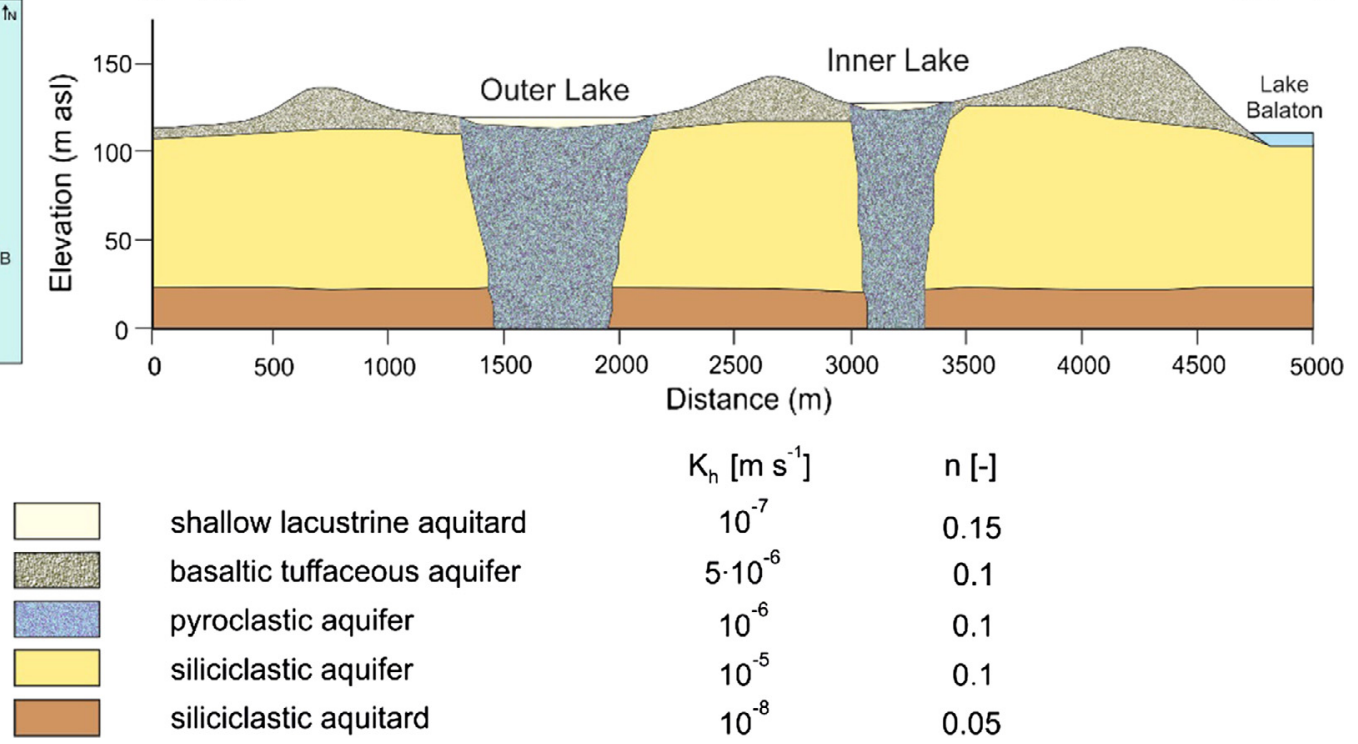

$\begin{array}{cc}\mathrm{K}_{\mathrm{h}}\left[\mathrm{m} \mathrm{s}^{-1}\right] & \mathrm{n}[-] \\ 10^{-7} & 0.15 \\ 5 \cdot 10^{-6} & 0.1 \\ 10^{-6} & 0.1 \\ 10^{-5} & 0.1 \\ 10^{-8} & 0.05\end{array}$

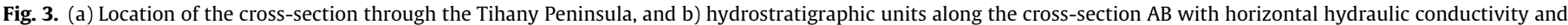
porosity values.

previous numerical studies which showed that most groundwater flow takes place above this aquitard (Tóth et al., 2016).

Across the upper flow model boundary, outside of the local lake areas with constant head, a specific recharge was defined, calculated from hydrologic parameters based on years with high, average and low water level conditions for the steady-state simulations, and based on climatic predictions (Fig. 2) in the transient simulation. During the steady-state simulations, the water levels of Inner and Outer Lakes were defined as fixed heads based on measured data (Table 1).

Since the climate-change induced water level variations were the focus of interest in the transient simulation, the fixed heads assigned to represent the steady-state lake levels were eliminated (Table 2). In addition, the water table configuration obtained from the steady-state simulation representing the average water level condition was used as the initial condition for the transient flow model. Thus the watertable elevation change below and between the lakes was calculated by the model based on the predicted decrease of recharge across the top boundary over each time step.

Based on historical observations and theoretical considerations (see Section 3.1), an annual $0.025 \mathrm{~m}$ decrease in the water level of Lake Balaton was assumed in the future. Along the two lateral (vertical) boundaries, a water discharge flux of $16 \mathrm{~mm} \mathrm{yr}^{-1}$ $\left(5 \times 10^{-10} \mathrm{~m} \mathrm{~s}^{-1}\right)$ was assigned (Table 1$)$ to reflect groundwater discharge to Lake Balaton, as estimated by previous studies (Havril et al., 2012; Tóth et al., 2016), and to represent flow towards the low-elevation neck of the peninsula.

\section{Results}

\subsection{Steady-state simulation}

The main characteristic feature of the current flow conditions (which can be considered as representing yearly average water level conditions), is the nested groundwater flow system with local and intermediate systems. Inner Lake represents the main recharge area along the studied section due to its relatively high elevation and therefore high hydraulic potential. Moreover, Inner Lake can be considered as a groundwater divide which separates the flow system of the peninsula into two main parts: i) A flow system where groundwater recharge from Inner Lake flows through the saturated zone to the lower hydraulic potential area of Outer Lake (by local flow system "L2"; Fig. 4.b), and toward the neck of the peninsula (by intermediate flow system "I"), as well as ii) A flow system from Inner Lake toward Lake Balaton (by local flow system “L3"; Fig. 4.b).

Table 1

Boundary conditions for the steady-state model.

\begin{tabular}{|c|c|c|c|c|c|}
\hline \multicolumn{2}{|l|}{ Position } & \multirow{2}{*}{$\begin{array}{l}\text { Flow } \\
\text { condition }\end{array}$} & \multirow{2}{*}{$\begin{array}{l}\text { Value of high water level } \\
\text { condition }\end{array}$} & \multirow[t]{2}{*}{$\begin{array}{l}\text { Value of average water level } \\
\text { condition }\end{array}$} & \multirow[t]{2}{*}{$\begin{array}{l}\text { Value of low water level } \\
\text { condition }\end{array}$} \\
\hline Bottom & $0-5000 \mathrm{~m}$ & & & & \\
\hline Left & $0-130 \mathrm{~m}$ & Fluid flux & $-16 \mathrm{~mm} \mathrm{yr}^{-1}$ (outflow) & & \\
\hline Right & $0-130 \mathrm{~m}$ & Fluid flux & $-16 \mathrm{~mm} \mathrm{yr}^{-1}$ (outflow) & & \\
\hline \multirow[t]{7}{*}{ Top } & $\begin{array}{l}0-100 \mathrm{~m} \text { (neck of the } \\
\text { peninsula) }\end{array}$ & Fixed head & $106.4 \mathrm{~m}$ & & \\
\hline & $100-1300 \mathrm{~m}$ & Fluid flux & $394 \mathrm{~mm} \mathrm{yr}^{-1}$ & $165 \mathrm{~mm} \mathrm{yr}^{-1}$ & $55 \mathrm{~mm} \mathrm{yr}^{-1}$ \\
\hline & 1300-2100 m (Outer Lake) & Fixed head & $116.0 \mathrm{~m}^{*}$ & $115.6 \mathrm{~m}^{*}$ & $115.3 \mathrm{~m}^{*}$ \\
\hline & $2100-3000 \mathrm{~m}$ & Fluid flux & $394 \mathrm{~mm} \mathrm{yr}^{-1}$ & $165 \mathrm{~mm} \mathrm{yr}^{-1}$ & $55 \mathrm{~mm} \mathrm{yr}^{-1}$ \\
\hline & 3000-3400 m (Inner Lake) & Fixed head & $127.4 \mathrm{~m}^{*}$ & $126.9 \mathrm{~m}^{*}$ & $126.5 \mathrm{~m}^{*}$ \\
\hline & $3400-4800 \mathrm{~m}$ & Fluid flux & $394 \mathrm{~mm} \mathrm{yr}^{-1}$ & $165 \mathrm{~mm} \mathrm{yr}^{-1}$ & $55 \mathrm{~mm} \mathrm{yr}^{-1}$ \\
\hline & 4800-5000 m (Lake Balaton) & Fixed head & $104.4 \mathrm{~m}$ & & \\
\hline
\end{tabular}

* Hydraulic head value based on site-specific measurement. 
Table 2

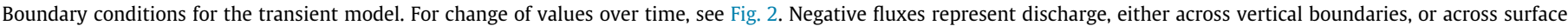
water (ex. Outer Lake which retains surface water).

\begin{tabular}{|c|c|c|c|c|c|}
\hline Position & & Flow condition & Current value & Predicted value after $80 \mathrm{yr}$ & Extrapolated value after $100 \mathrm{yr}$ \\
\hline Bottom & $0-5000 \mathrm{~m}$ & No-flow & $0 \mathrm{~m} \mathrm{~s}^{-1}$ & $0 \mathrm{~m} \mathrm{~s}^{-1}$ & $0 \mathrm{~m} \mathrm{~s}^{-1}$ \\
\hline Left & $0-130 \mathrm{~m}$ & Fluid flux & $-16 \mathrm{~mm} \mathrm{yr}^{-1}$ (outflow) & & \\
\hline Right & $0-130 \mathrm{~m}$ & Fluid flux & $-16 \mathrm{~mm} \mathrm{yr}^{-1}$ (outflow) & & \\
\hline \multirow[t]{5}{*}{ Top } & $0-100 \mathrm{~m}$ (neck of the peninsula) & Fixed head & $106.4 \mathrm{~m}$ & $105.4 \mathrm{~m}$ & $104.9 \mathrm{~m}$ \\
\hline & $100-1300 \mathrm{~m}$ & Fluid flux & $165 \mathrm{~mm} \mathrm{yr}^{-1}$ & $54 \mathrm{~mm} \mathrm{yr}^{-1}$ & $37 \mathrm{~mm} \mathrm{yr}^{-1}$ \\
\hline & $1300-2100$ m (Outer Lake) & Fluid flux & $-3 \mathrm{~mm} \mathrm{yr}^{-1}$ & $-2 \mathrm{~mm} \mathrm{yr}^{-1}$ & $-2 \mathrm{~mm} \mathrm{yr}^{-1}$ \\
\hline & $2100-4800 \mathrm{~m}$ & Fluid flux & $165 \mathrm{~mm} \mathrm{yr}^{-1}$ & $54 \mathrm{~mm} \mathrm{yr}^{-1}$ & $37 \mathrm{~mm} \mathrm{yr}^{-1}$ \\
\hline & 4800-5000 m (Lake Balaton) & Fixed head & $104.4 \mathrm{~m}$ & $103.4 \mathrm{~m}$ & $102.9 \mathrm{~m}$ \\
\hline
\end{tabular}

(a) High water level condition

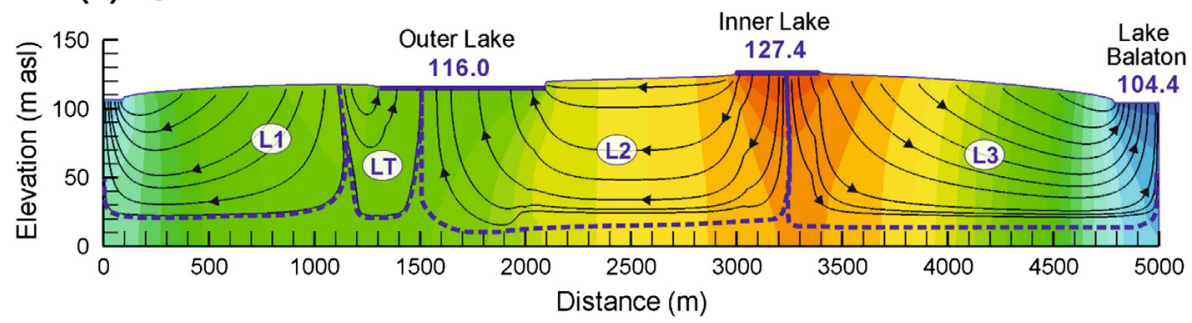

(b) Average water level condition

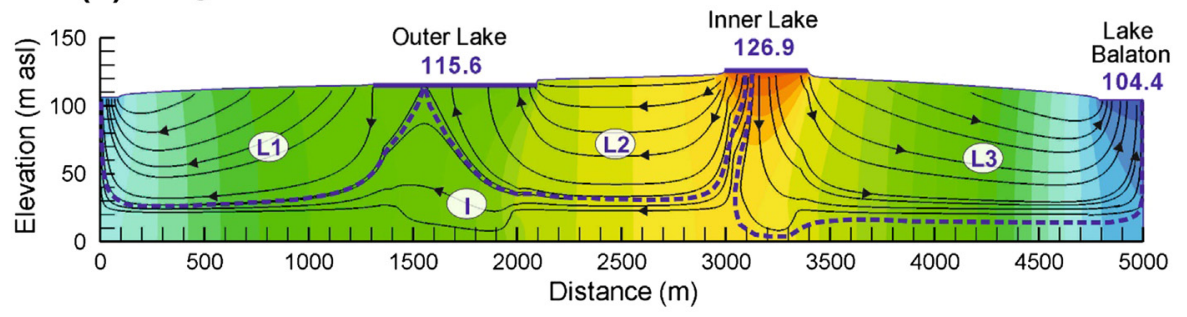

(c) Low water level condition

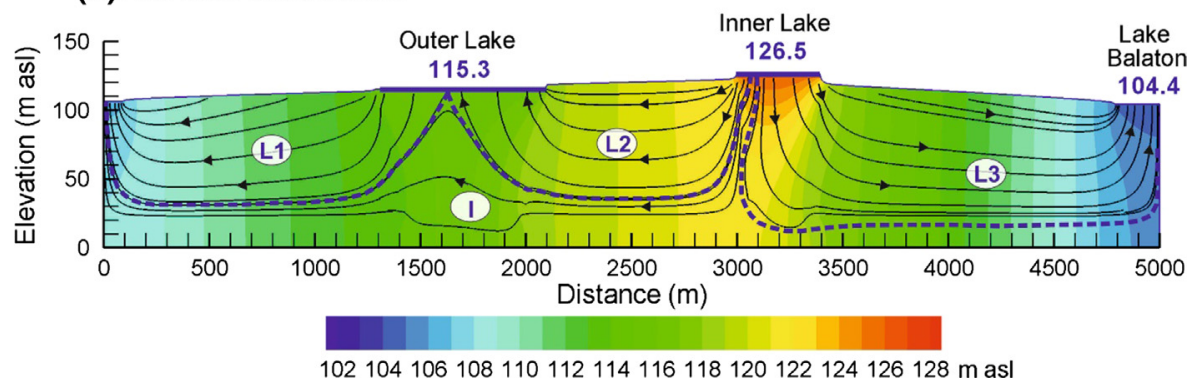

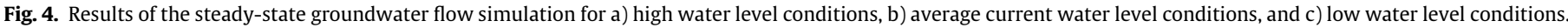

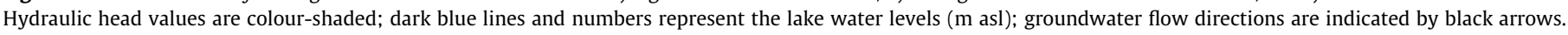

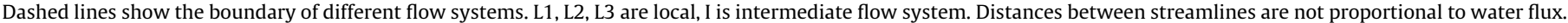
For boundary conditions see Table 1 . Cross-section has $7 \times$ vertical exaggeration.

In order to examine the effect of shorter-scale climatic variability on groundwater levels and flow conditions, two hydrological extreme years were also tested using the steady-state model, i.e. high water level conditions (Fig. 4.a, based on water level measurements in the wet year 2010) and low water level conditions (Fig. 4.c, based on water level measurements in the dry year 2011).

Results of the steady-state simulations suggested that a single extreme dry year does not cause any significant changes in the potential distribution compared to average water level conditions, and has only minor effects on groundwater levels (with a groundwater level decrease of $<0.5 \mathrm{~m}$ ) and on flow velocities. The main characteristics of the flow system, namely the three local systems ("L1", "L2" and "L3") and the intermediate system ("I") remain the same (Fig. 4.c).
On the other hand, extreme wet conditions (Fig. 4.a) lead to the development of a groundwater mound between Outer Lake and the neck of the peninsula, approximately $1100 \mathrm{~m}$ from the left boundary, which modified the flow directions compared to the same area under lower groundwater level conditions (Fig. 4.b and c). This groundwater mound functions as a water divide, therefore flow of groundwater from the main recharge area (i.e. from the basin of Inner Lake) toward the neck of the peninsula (via intermediate flow system "I") is inhibited. The result is a fragmented flow field due to the development of a new, temporary local flow system (flow system "LT"), and consequently, groundwater discharges along the entire base of Outer Lake (Fig. 5). Moreover, with the suppression of the former intermediate flow system "I", the flow system hierarchy changed from a nested flow system to a set of single local flow cells. 


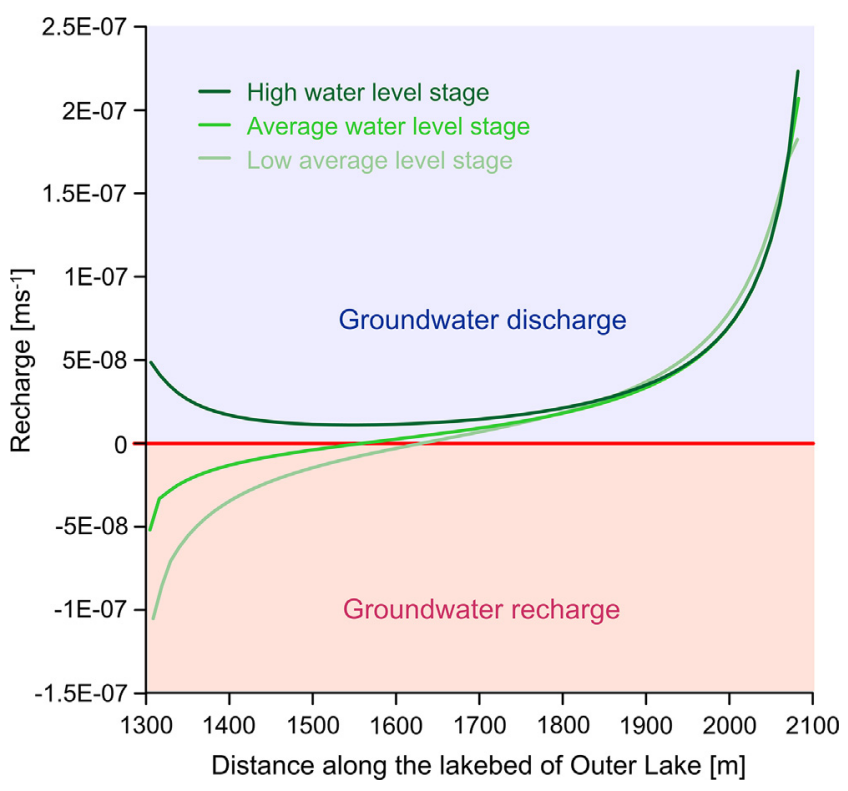

Fig. 5. Variations of vertical Darcy flux along the lakebed of Outer Lake during high, average and low water level conditions. Positive vertical Darcy fluxes represent upward flow, reflecting groundwater discharge into Outer Lake in the upgradient (right) part of the lake. Negative vertical Darcy fluxes indicate downward flow, as groundwater is recharged from Outer Lake at the downgradient end. Horizontal distances from Fig. 4.

\subsection{Transient simulation}

Starting from the steady-state model of average water level conditions (Fig. 4.b), a transient simulation was run using longerscale climate change, which induced transient water table fluctuations.

Prior to running the long-term transient flow simulation, a sensitivity analysis was performed regarding the effects of a future decrease in water levels of Lake Balaton, and its potential effects on the flow field. Taking into account that the lake is shallow (an approx. $4 \mathrm{~m}$ water level decrease would almost completely drain the lake) and considering historical water level changes of the lake, realistic decreases of $1 \mathrm{~m}$ and $4 \mathrm{~m}$ were tested. Results of the sensitivity analysis did not show significant differences in groundwater levels and in the general flow patterns between the tested cases. Therefore an estimated $1 \mathrm{~m}$ drop in water level of Lake Balaton was applied over the coming century.

The results show that during the simulated $100 \mathrm{yr}$ time period, the groundwater flow field along the cross-section changed significantly. The most substantial change was the gradual degradation of local flow system "L2" between Inner Lake and Outer Lake. Currently, a significant fraction of the water that recharges through Inner Lake is transmitted toward Outer Lake through this local L2 flow system with a maximum penetration depth of approx. $70 \mathrm{~m}$ (i.e. the deepest flowline along which water is transmitted to Outer Lake; Fig. 6.a). This penetration depth gradually decreases over time (from approx. $70 \mathrm{~m}$ to $50 \mathrm{~m}$ after $20 \mathrm{yr}$, and to $10 \mathrm{~m}$ after $80 \mathrm{yr}$ ). By the end of the century, the predicted flow field suggests that most water from Inner Lake will flow directly toward the neck of the peninsula under Outer Lake via intermediate flow system "I", with only limited flow-through via Outer Lake and the shallow local flow system "L2" (Fig. 6.d).

After approx. 80 years, only a minor part of the flow system (44\%) discharges directly into the lakebed of Outer Lake (Fig. 7) due to the flattening of the water table across the entire peninsula, which causes a migration and relocation of the discharge area. As a consequence, inter-lake flow-through almost completely disappears by $80 \mathrm{yr}$, which decreases the fragmentation of the groundwater flow field and simplifies its flow pattern. While over the first 80 years (Fig. 6.a-d), the simulation results showed significant changes in flow directions and a strongly attenuated flow system hierarchy, in the last 20 years, the main characteristics of the flow field remain essentially unchanged, in which the most dominant change can be observed in groundwater levels.

Another clear result of the transient simulation was the continuous decrease in groundwater level below Inner Lake, which dropped below the bottom of the lakebed (below $124.4 \mathrm{~m}$ asl) after approx. 30-35 years. These conditions could thus lead to the gradual shrinkage and eventual drying of the lake (Fig. 6.b and c).

In the case of Outer Lake, changes caused by the reduced recharge had a less significant impact on groundwater levels by the end of the century (Fig. 6.d). However, the simulation results suggest that Outer Lake receives subsurface recharge from Inner Lake through a gradually smaller part of its lakebed, and in parallel, Outer Lake transmits the water toward the neck of the peninsula through a gradually larger part of its lakebed. While Outer Lake discharges groundwater along $88 \%$ of its lakebed after 20 years (between 1400-2100 m, Fig. 7), at the end of the century this percentage decreases to $44 \%$.

A more significant decrease in groundwater level beneath Inner Lake compared to Outer Lake led to a decrease in the hydraulic gradient between these two lakes and to a decrease of the flow rates, which can be followed by the vertical Darcy flux distribution along the cross-section (Fig. 8). Within the simulated $100 \mathrm{yr}$ time interval, the local groundwater level remains above the deepest point of Outer Lake's lakebed (where the lakebed elevation is $114.6 \mathrm{~m}$ asl), which reflects a lower sensitivity of Outer Lake to decreasing recharge (Fig. 6.e) compared to Inner Lake.

\section{Interpretation and discussion}

The 2D transient groundwater flow simulation study carried out for the Tihany Peninsula study site focused on understanding the effects of decreasing recharge due to climate change. The results showed a high probability of significant future changes to the groundwater flow field, water levels and fluxes due to climatic influence.

The most important change during the transient simulation was related to modification of the flow system hierarchy along the studied section, in which the current local flow system between Inner and Outer Lakes gradually degrades over time, rendering the groundwater flow field less fragmented and more uniform. As groundwater levels decrease, horizontal flow becomes dominant, and the character of groundwater discharge into Outer Lake, i.e. the groundwater - surface water interaction, is modified (Fig. 6).

Effects of shorter-scale climatic variability (i.e. extreme wet and dry periods) can cause dynamic growth and dissipation of transient local groundwater flow systems, as simulated at the study site during high water level conditions. In particular, a groundwater mound develops downgradient from Outer Lake, which functions as a local water divide, restricting the transmission of groundwater from the main divide and recharge area (Inner Lake) toward the neck of the peninsula. As a consequence, a fragmented flow field develops which modifies the groundwater - surface water interaction, allowing groundwater discharge along the whole basin of Outer Lake (Fig. 5). With suppression of the former intermediate flow system, the flow system hierarchy changes from a nested flow system to a set of single local flow cells (Fig. 4.a).

These findings are in agreement with the results of Liang et al. (2013), who showed that as groundwater recharge gradually decreases, the flow pattern changes from (i) a fragmented flow field with separated local cells, to (ii) a less fragmented flow field 


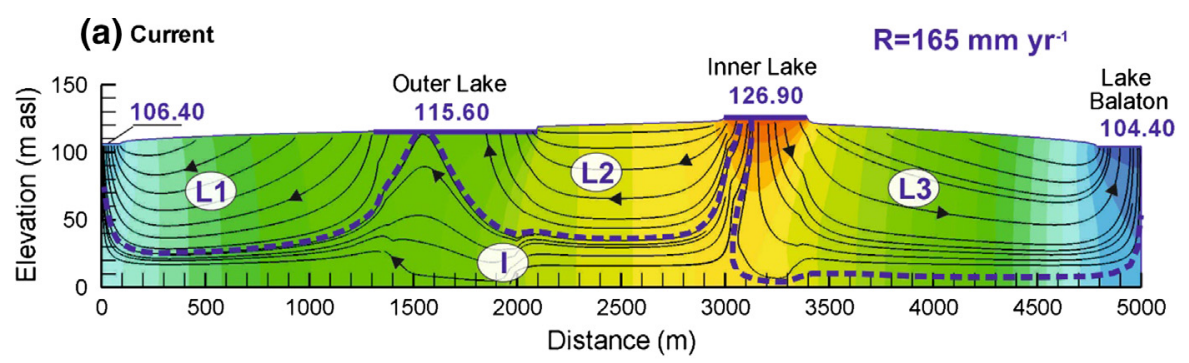

(b) After 20 yr (approx. 2040)

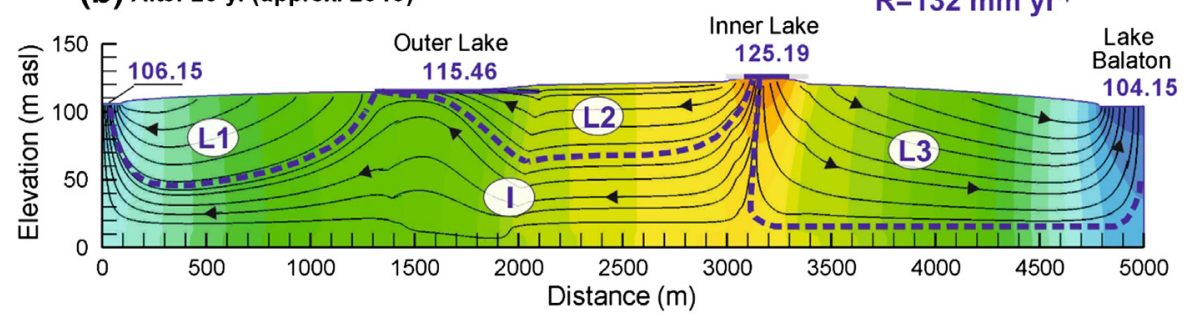

(c) After 40 yr (approx. 2060)

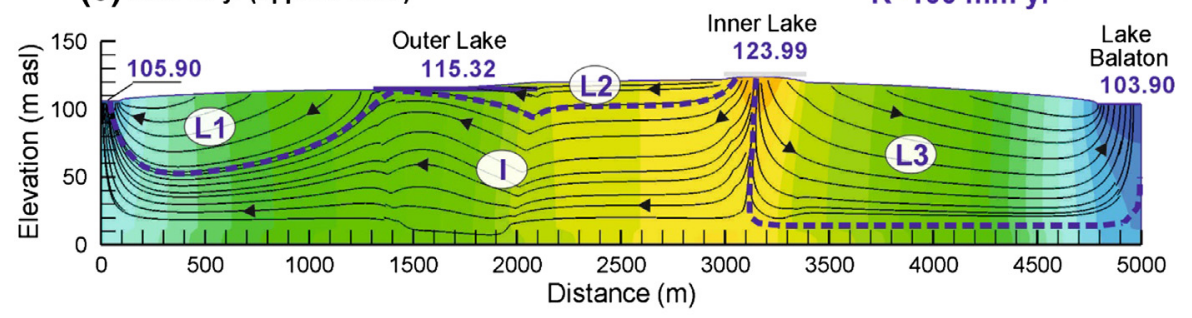

(d) After 80 yr (approx. 2100)

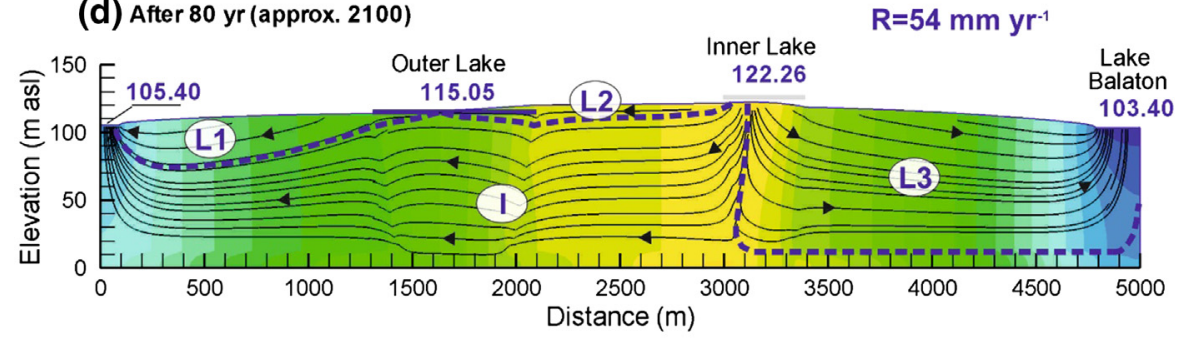

(e) After 100 yr (approx. 2120)

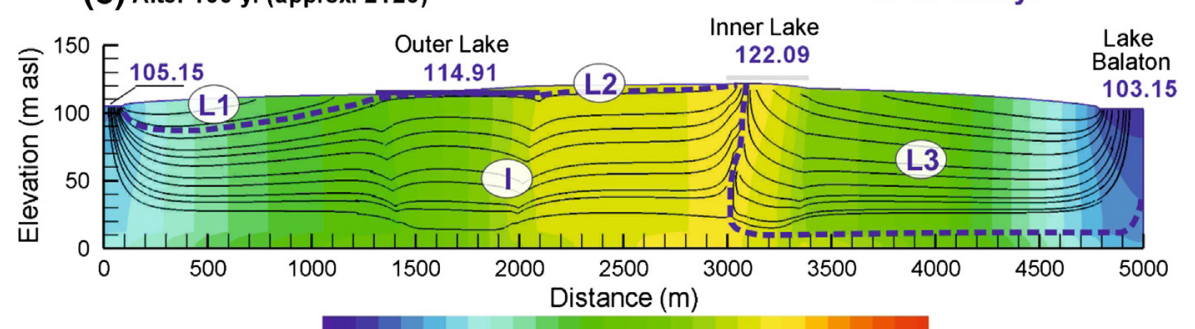

102104106108110112114116118120122124126128 m asl

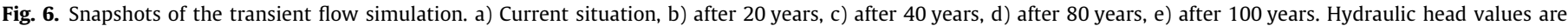

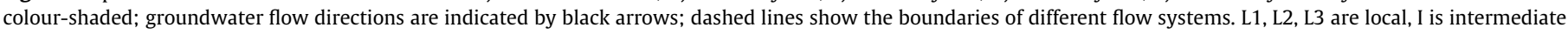

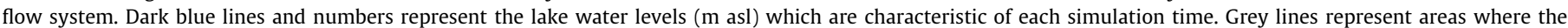

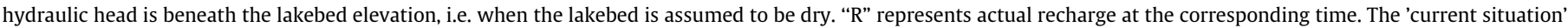

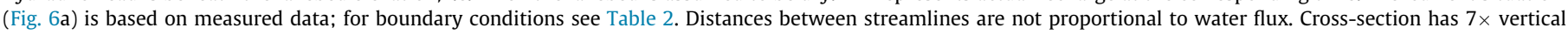
exaggeration.

with nested flow systems (including local, intermediate and regional cells) and to (iii) a single regional flow cell. However, in the current study, regional flow cells do not develop due to the limited spatial dimensions of the study site.

Another question addressed by the current study related to the effects of modified flow patterns on surface water bodies and potential consequences on groundwater-dependent ecosystems. Based on the transient simulation results, the groundwater level is predicted to decrease below the bottom of Inner Lake in approx. 30-35 years, by which time the lakebed is assumed to become dry, and the lake will disappear (Fig. 6). Nevertheless, due to flowfocusing and surface runoff, the groundwater mound below the lake bottom will likely remain, and thus its function as a recharge area should not significantly change over the next 100 years.

Outer Lake appears less sensitive to decreasing precipitation due to the buffering effect of continuous (but decreasing) subsur- 


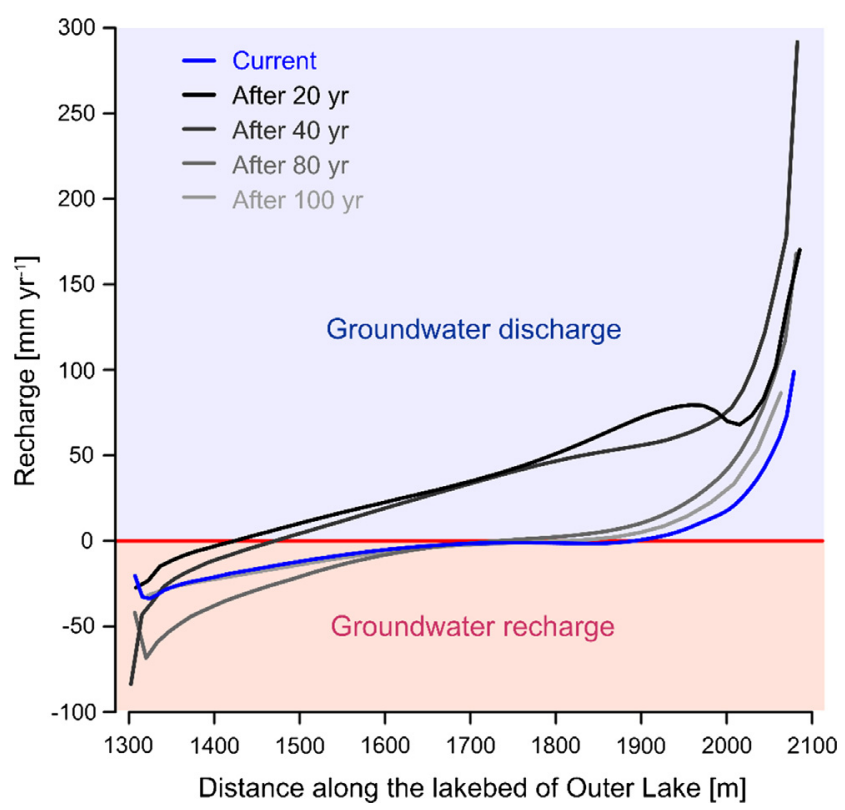

Fig. 7. Variations of vertical Darcy flux along the lakebed of Outer Lake during the transient simulation. Positive vertical Darcy fluxes represent upward flow, reflecting groundwater discharge into Outer Lake. Negative vertical Darcy fluxes indicate downward flow, as groundwater is recharged from Outer Lake.

face inflow from higher elevations. The transient simulations show that its water level does not drop significantly by the end of the century (Fig. 6), primarily because it receives subsurface inflow from Inner Lake, albeit through a gradually smaller part of its lakebed which at the end of the century has dropped to approx. $44 \%$ (Fig. 7), and in parallel horizontal flow becomes dominant (Figs. 6, 8).

The different behavior of Inner and Outer Lake is consistent with the findings of Zhao et al. (2016) who examined transient behavior of nested flow systems and found that water table fluctuations are greatest near the flow divides and are less variable in the main discharge areas.
Although beyond the scope of this study, a further question can arise as to how long it would take for a given groundwater flow system to respond to modified climatic conditions if the variation of recharge is not continuous (as assumed in this study) but intermittent? As Gong et al. (2015) highlighted, response time is not uniform within the system, because the critical parameters controlling the response-time behavior of the groundwater system (i.e. recharge) differ from those controlling the response-time behavior of the lake (i.e. leakage though the lakebed etc.). Moreover, distal parts of the groundwater system respond more slowly than areas midway between the lake and basin boundary.

The time lag is governed by features of the groundwater system, expressed by Domenico and Schwartz (1998) as $\mathrm{S}_{\mathrm{s}} \mathrm{L}^{2} / \mathrm{K}$, where $\mathrm{S}_{\mathrm{s}}$ is specific storage, $\mathrm{L}$ is some characteristic length, and $\mathrm{K}$ is hydraulic conductivity. Therefore care must be taken when defining specific storage, since it could have important effects on transient processes (e.g. alteration of groundwater flow systems due to changing recharge rates).

As can be inferred from the current simulations, changes in the groundwater flow system would have implications in water and nutrient budgets of dependent wetlands. Over long time scales, the flow rates are reduced and lower hydraulic gradients between Inner and Outer Lakes (Fig. 8) generated less groundwater recharge into Outer Lake from Inner Lake (Fig. 7). These changes could also have a substantial effect on water chemistry and on groundwaterdependent ecosystems. Green et al. (2011) provide an overview and synthesis of the key aspects of subsurface hydrology related to global climate variability, which has implications for both water quantity and quality.

Climate change may affect the quality of surface- and groundwater in several ways, from changes in the subsurface thermal regime (Aureli and Taniguchi 2006, Kurylyk et al. (2014), through various altered biogeochemical reactions due to modified nutrient fluxes (e.g. nitrogen and phosphorus) (Destouni and Darracq, 2009), to eutrophication of surface water which will enhance the loss of biodiversity and ecosystem services (Green et al., 2017; Neumann et al., 2017).

In the Tihany study area, the penetration depth of the current local flow system between Inner and Outer lakes gradually

(a) Current

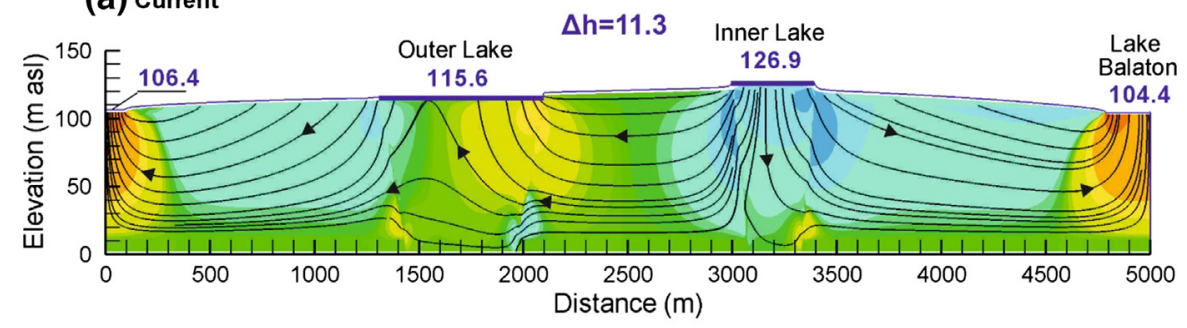

(b) After 100 yr (approx. 2120)

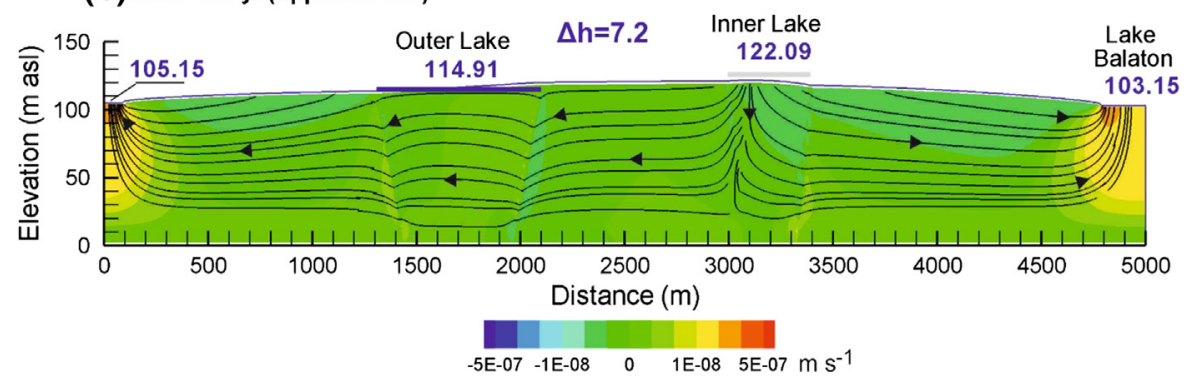

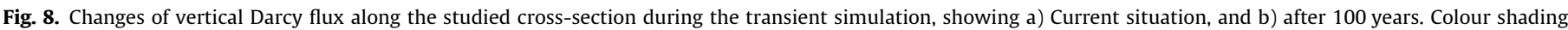

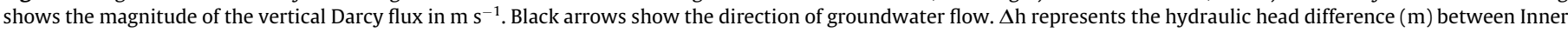
and Outer Lake at the corresponding times. Lake and boundary elevations in metres (asl). 
decreases over time (Figs. 5, 6), the flow system becomes shallower, and groundwater fluxes decrease (Fig. 8). The temperature of the groundwater discharging to Outer Lake would therefore gradually become warmer, as observed elsewhere due to warming air temperatures measured over the last century (e.g. Figura et al., 2011, Menberg et al., 2014). Increases in groundwater temperatures could impact biogeochemical processes, and therefore groundwater quality, which could also harm groundwaterdependent ecosystems (Green et al., 2011, Sharma et al., 2012, Kurylyk et al., 2014). Additionally, as Johnson et al. (2005) highlighted, productive wetlands may become only marginally productive in a warmer, drier future climate.

\section{Conclusions and summary}

Interest has grown rapidly over the last decade regarding the effects of future hydrologic conditions on groundwater. However, studies that focus on the modification of subsurface flow hierarchy, i.e. changes in flow system dimension and relationships between local, intermediate and regional flow systems, are currently underrepresented in the scientific literature. As known from previous studies, local flow systems are affected the most by climate change, compared to intermediate or regional systems. The most important consequence is that modification of local flow systems can influence groundwater - surface water interaction, which can significantly increase stress to ecological wetland communities and to other groundwater-dependent ecosystems.

Therefore, the current study aimed to examine the influence of changing recharge due to climate trends on groundwater levels. In addition, coupled effects were interpreted based on the interconnected groundwater flow systems with special emphasis on the development of flow system hierarchy. Possible consequences on groundwater-related shallow surface water bodies and groundwater - surface water interaction were also investigated.

The results showed that effects of climatic recharge variability can cause dynamic growth and dissipation of transient local groundwater flow systems, and the characteristics of flow system hierarchy could change from nested flow systems to a set of single flow cells. These changes could have significant effects on groundwater - surface water interaction, since a decrease in groundwater level could change the character of groundwater discharge into a surface water body, as occurred in the case of Outer Lake. By the end of the simulated period, hydraulic head differences along the water table had decreased and horizontal flow became dominant.

Hydraulic behavior and response of surface water bodies located at distinct surface elevations - to recharge variations in successive years, can be explained by fluctuations in the water table which are greatest at the groundwater divides, while the water table is more stable in the main discharge area.

The study also suggests that a reduction in groundwater levels under climate-driven recharge change could strongly affect ecologically-significant flow regimes. Moreover, since water and nutrient budgets of groundwater-related surface waters are strongly influenced by groundwater, wetland water quality could also change in the future.

At the Tihany Peninsula, preservation of associated groundwater-dependent ecosystems would be challenging since long-term climate change could potentially have serious consequences, including wetland disappearance. Although no substantial anthropogenic drivers have affected the groundwater system at the Tihany site, at other sites where groundwater extraction is occurring, the effects of climate change could be even more significant.

Predictions regarding future subsurface processes are highly uncertain because of the unpredictable degree of climate change and numerous possible feedback processes. Understanding the effects of climate change on flow patterns and rechargedischarge relationships with surface water bodies can nevertheless help to better mitigate or prepare for the consequences, e.g. with improved water management plans and policies in order to protect these vulnerable water resources or to develop them in a sustainable manner.

\section{Acknowledgement}

This research was supported by the New National Excellence Program of the Ministry of Human Capacities, Hungary, and by the János Bolyai Research Scholarship of the Hungarian Academy of Sciences. Financial and technical support from the Department of Physical and Applied Geology, Eötvös Loránd University, during field work is appreciated. The authors gratefully acknowledge this research opportunity provided by the Balaton Highlands National Park, Hungary, with special thanks to József Vers.

\section{References}

Aguilera, H., Murillo, J.M., 2009. The effect of possible climate change on natural groundwater recharge based on a simple model: a study of four karstic aquifers in SE Spain. Environ. Geol. 57 (5), 963-974.

An, R., Jiang, X.W., Wang, J.Z., Wan, L., Wang, X.S., Li, H., 2015. A theoretical analysis of basin-scale groundwater temperature distribution. Hydrogeol. J. 23 (2), 397404.

Aureli, A., Taniguchi, M., 2006. Groundwater Assessment under the Pressures of Humanity and Climate Changes-GRAPHIC, GRAPHIC Series No. 1. United Nations Educational, Scientific, and Cultural Organization, Paris.

Barron, O., Silberstein, R., Ali, R., Donohue, R., McFarlane, D.J., Davies, P., Hodgson, G. Smart, N., Donn, M., 2012. Reprint of: "Climate change effects on waterdependent ecosystems in south-western Australia" [J. Hydrol. 434-435 (2012) 95-109]. J. Hydrol. 475, 473-487.

Bartholy, J., Bogardi, I., Matyasovszky, I., 1995. Effect of climate change on regional precipitation in the Lake Balaton watershed. Theoret. Appl. Climatol. 51 (4), 237-250.

Bartholy, J., Pongrácz, R., Pieczka, I., 2014. How will the climate change in this century? Hungarian Geograph. Bull. 63, 55-67 (BJ-et-alHunGeoBull_2014_1_55-67.pdf).

Bates, B., Kundzewicz, Z.W., Wu, S., Palutikof, J., 2008. Climate change and water: Technical Paper vi. Intergovernmental Panel on Climate Change (IPCC).

Bear, J., 1972. Dynamics of Fluids in Porous Media. American Elsevier Publishing Company, Inc., New York (784 pp.).

Brouyère, S., Carabin, G., Dassargues, A., 2004. Climate change impacts on groundwater resources: modelled deficits in a chalky aquifer, Geer basin Belgium. Hydrogeol. J. 12 (2), 123-134.

Candela, L., Tamoh, K., Olivares, G., Gomez, M., 2012. Modelling impacts of climate change on water resources in ungauged and data-scarce watersheds. Application to the Siurana catchment (NE Spain). Sci. Total Environ. 440, 253260.

Chen, Z., Grasby, S.E., Osadetz, K.G., 2004. Relation between climate variability and groundwater levels in the upper carbonate aquifer, southern Manitoba Canada. J. Hydrol. 290 (1), 43-62.

Cheng, X., Anderson, M.P., 1994. Simulating the influence of lake position on groundwater fluxes. Water Resour. Res. 30 (7), 2041-2049.

Destouni, G., Darracq, A., 2009. Nutrient cycling and N2O emissions in a changing climate: the subsurface water system role. Environ. Res. Lett. 4 (3), 035008.

Domenico, P.A., Schwartz, F.W., 1998. Physical and Chemical Hydrogeology, vol. 506. Wiley, New York.

Döll, P., Fiedler, K., 2007. Global-scale modeling of groundwater recharge. Hydrol. Earth Syst. Sci. Discussions 4 (6), 4069-4124.

Earman, S., Dettinger, M., 2011. Potential impacts of climate change on groundwater resources-a global review. J. Water Clim. Change 2 (4), 213-229.

European Commission, website: http://ec.europa.eu/environment/nature/natura 2000/index en.htm, Last visited: 16.06.2017.

Figura, S., Livingstone, D.M., Hoehn, E., Kipfer, R., 2011. Regime shift in groundwater temperature triggered by the Arctic Oscillation. Geophys. Res. Lett. 38 (23).

Gondár-Sőregi, K., Gondár, K., 1988. A Balaton-felvidék alaphegységi formációinak vízföldtani jellemzői. Hidrológiai Közlöny 68 (6), 349-356 (in Hungarian).

Gong, Y., Liu, G., Schwartz, F.W., 2015. Quantifying the response time of a lakegroundwater interacting system to climatic perturbation. Water 7 (11), 65986615.

Green, T.R., Taniguchi, M., Kooi, H., Gurdak, J.J., Allen, D.M., Hiscock, K.M., Treidel, H., Aureli, A., 2011. Beneath the surface of global change: impacts of climate change on groundwater. J. Hydrol. 405 (3), 532-560.

Green, A.J., Alcorlo, P., Peeters, E.T., Morris, E.P., Espinar, J.L., Bravo-Utrera, M.A. Bustamante, J., Díaz-Delgado, R., Koelmans, A.A., Mateo, R., RodríguezRodríguez, M., van Nes, E.H., Scheffer, M., Mooij, W.M., 2017. Creating a safe 
operating space for wetlands in a changing climate. Front. Ecol. Environ. 15 (2), 99-107.

G-Tóth, L., Parpala, L., Balogh, C., Tàtrai, I., Baranyai, E., 2011. Zooplankton community response to enhanced turbulence generated by water-level decrease in Lake Balaton, the largest shallow lake in Central Europe. Limnol. Oceanogr. 56 (6), 2211-2222.

Gurdak, J.J., 2008. Ground-Water Vulnerability: Nonpoint-Source Contamination, Climate Variability, and the High Plains Aquifer. VDM Publishing.

Haas, J., Hámor, G., Korpás, L., 1999. Geological setting and tectonic evolution of Hungary. Geologica Hungarica Series, Geologica 24, 179-196.

Hanson, R.T., Flint, L.E., Flint, A.L., Dettinger, M.D., Faunt, C.C., Cayan, D., Schmid, W., 2012. A method for physically based model analysis of conjunctive use in response to potential climate changes. Water Resour. Res. 48 (6).

Havril, T., 2012. Felszínalatti vizek és tavak kölcsönhatásának időbeli és térbeli elemzése helyszíni mérések és numerikus szimuláció segítségével a Tihanyifélszigeten (in Hungarian). MSc Theses, ELTE Eötvös Loránd University, Budapest, Hungary, 83 p.

Havril, T., Tóth, Á., Mádl-Szőnyi, J., Simon, Sz., Palmer, S., Müller, I., 2012. Maar lakes in subsurface flow connection, Tihany Penninsula, Hungary. In: 39th International Association of Hydrogeologists Congress: Congress Program and Abstracts, Niagara Falls, Canada, pp. 307-308, 2012.09.16-2012.09.21.

Herrera-Pantoja, M., Hiscock, K.M., 2008. The effects of climate change on potential groundwater recharge in the Great Britain. Hydrol. Process. 22 (1), 73-86.

Horváth, F., Sacchi, M., Dombrádi, E., 2010. Seismic stratigraphy and tectonics of Late Miocene basin fill in southern Transdanubia and below Lake Balaton. Földtani Közlöny 140 (4), 391-418.

Johnson, W.C., Millett, B.V., Gilmanov, T., Voldseth, R.A., Guntenspergen, G.R., Naugle, D.E., 2005. Vulnerability of northern prairie wetlands to climate change. Bioscience 55 (10), 863-872.

Jyrkama, M.I., Sykes, J.F., 2007. The impact of climate change on spatially varying groundwater recharge in the Grand River watershed (Ontario). J. Hydrol. 338 (3), 237-250.

Kløve, B., Ala-Aho, P., Bertrand, G., Gurdak, J.J., Kupfersberger, H., Kværner, J., Uvo, C. B., 2014. Climate change impacts on groundwater and dependent ecosystems. J. Hydrol. 518, 250-266.

Kløve, B., Ala-Aho, P., Bertrand, G., Boukalova, Z., Ertürk, A., Goldscheider, N., Ilmonen, J., Karakaya, N., Kupfersberger, H., Kvœrner, J., Lundberg, A., Mileusnić, M., Moszczynska, A., Muotka, T., Preda, E., Rossi, P., Siergieiev, D., Simek, J., Wachniew, P., Angheluta, V., Widerlund, A., 2011a. Groundwater dependent ecosystems. Part I: Hydroecological status and trends. Environ. sci. \& policy 14 (7), 770-781.

Kløve, B., Allan, A., Bertrand, G., Druzynska, E., Ertürk, A., Goldscheider, N., Henry, S., Karakaya, N., Karjalainen, T.P., Koundouri,, P., Kupfersberger, P., Kvœrner, J., Lundberg, A., Muotka, T., Preda, E., Pulido-Velazquez, M., Schipper, P., 2011b. Groundwater dependent ecosystems. Part II. Ecosystem services and management in Europe under risk of climate change and land use intensification. Environ. sci. \& policy 14 (7), 782-793.

Kovalevskii, V.S., 2007. Effect of climate changes on groundwater. Water Resour. 34 (2), 140-152.

Kundzewicz, Z.W., Mata, L.J., Arnell, N.W., Döll, P., Jimenez, B., Miller, K., Oki, T., Sen, Z., Shiklomanov, I., 2008. The implications of projected climate change for freshwater resources and their management. Hydrolog. Sci. J. 53 (1), 3-10.

Kurylyk, B.L., MacQuarrie, K.T., Voss, C.I., 2014. Climate change impacts on the temperature and magnitude of groundwater discharge from shallow, unconfined aquifers. Water Resour. Res. 50 (4), 3253-3274.

Liang, X., Quan, D., Jin, M., Liu, Y., Zhang, R., 2013. Numerical simulation of groundwater flow patterns using flux as upper boundary. Hydrol. Process. 27 (24), 3475-3483.
Menberg, K., Blum, P., Kurylyk, B.L., Bayer, P., 2014. Observed groundwater temperature response to recent climate change. Hydrol. Earth Syst. Sci. 18 (11), 4453.

Molson, J.W., Frind, E.O., 2015. HEATFLOW - SMOKER Version 7.0 - Densitydependent Flow and Advective-dispersive Transport of Thermal Energy, Mass or Residence Time in Three-dimensional Porous or Discretely-fractured Porous Media. Université Laval, Quebec, QC, Canada.

Neumann, J., Cannata, M., Veronesi, M., Pera, S., 2017. Investigating climate change and groundwater related causes for eutrophication in Lake Lugano. In: EGU General Assembly Conference Abstracts, vol. 19, p. 18551.

Ng, G.H.C., McLaughlin, D., Entekhabi, D., Scanlon, B.R., 2010. Probabilistic analysis of the effects of climate change on groundwater recharge. Water Resour. Res. 46 (7).

Pieczka, I., Pongrácz, R., Bartholy, J., 2011. Comparison of simulated trends of regional climate change in the Carpathian Basin for the 21st century using three different emission scenarios. Acta Silvatica et Lignaria Hungarica 7, 9-22.

Sacchi, M., Horváth, F., Magyari, O., 1999. Role of unconformity-bounded units in the stratigraphy of the continental record: a case study from the Late Miocene of the western Pannonian basin, Hungary. In: Durand, B. (Ed.), The Mediterranean Basins: Tertiary Extension within the Alpine Orogen, vol. 156 Geological Society, London, pp. 357-390 (Special Publications).

Sandström, K., 1995. Modeling the effects of rainfall variability on groundwater recharge in semi-arid Tanzania. Hydrol. Res. 26 (4-5), 313-330.

Serrat-Capdevila, A., Valdés, J.B., Pérez, J.G., Baird, K., Mata, L.J., Maddock, T., 2007. Modeling climate change impacts-and uncertainty-on the hydrology of a riparian system: the San Pedro Basin (Arizona/Sonora). J. Hydrol. 347 (1), 48-66.

Sharma, L., Greskowiak, J., Ray, C., Eckert, P., Prommer, H., 2012. Elucidating temperature effects on seasonal variations of biogeochemical turnover rates during riverbank filtration. J. Hydrol. 428, 104-115.

Singh, A., 2014. Groundwater resources management through the applications of simulation modeling: a review. Sci. Total Environ. 499, 414-423. http://dx.doi. org/10.1016/j.scitotenv.2014.05.048.

Taylor, R.G., Scanlon, B., Döll, P., Rodell, M., Van Beek, R., Wada, Y., Longuevergne, L., Leblanc, M., Famiglietti, J.S., Edmunds, M., Konikow, L., Green, T.R., Chen, J., Taniguchi, M., Bierkens, M.F.P., MacDonald, A., Fan, Y., Maxwell, R.M., Yechieli, Y., Gurdak, J.J., Allen, D.M., Shamsudduha, M., Hiscock, K., Yeh, P.J.F., Holman, I., Treidel, H., 2013. Ground water and climate change. Nat. Clim. Change 3 (4), 322.

Tóth, Á., Havril, T., Simon, S., Galsa, A., Santos, F.A.M., Müller, I., Mádl-Szőnyi, J., 2016. Groundwater flow pattern and related environmental phenomena in complex geologic setting based on integrated model construction. J. Hydrol. 539, 330-344.

Tujchneider, O., Paris, M., Perez, M., D’Elia, M., 2012. Possible Effects of Climate Change on Groundwater Resources in the Central Region of Santa Fe Province, Argentina, pp. 265-280. In: Treidel, H., Martin-Bordes, J.J., Gurdak, J.J. (Eds.), Climate Change Effects on Groundwater Resources: A Global Synthesis of Findings and Recommendations, International Association of Hydrogeologists (IAH) - International Contributions to Hydrogeology. Taylor \& Francis Publishing, p. 414.

Turc, L., 1961. Estimation of irrigation water requirements, potential evapotranspiration: a simple climatic formula evolved up to date. Ann. Agron. $12(1), 13-49$.

Zhao, K.Y., Jiang, X.W., Wang, X.S., Wan, L., Wang, J.Z., Wang, H., Li, H., 2016. An analytical study on nested flow systems in a Tóthian basin with a periodically changing water table. J. Hydrol. 